\title{
Encounter rates and abundance of humpback whales (Megaptera novaeangliae) in Gerlache and Bransfield Straits, Antarctic Peninsula
}

\author{
Eduardo R. Secchi*+, Luciano Dalla Rosa*\#, Paul G. Kinas^, Raquel F. Nicolette^, Anne M. N. Rufino^ And \\ AleXANDRE F. AzEVEDO
}

Projeto Baleias/Brazilian Antarctic Programme (PROANTAR)

Contact email: edu.secchi@furg.br

\begin{abstract}
During the austral summer of 2006, the Projeto Baleias/Brazilian Antarctic Program (PROANTAR) conducted ship surveys for estimating whale encounter rates and abundance in Gerlache and Bransfield Straits, westward of the Antarctic Peninsula (edge between IWC Areas I and II). The encounter rate was higher in the Bransfield Strait (0.32 groups n. mile-1; 95\% CI: 0.26-0.39) than in the Gerlache Strait (0.24 groups n. mile-1; 95\% CI: 0.13-0.44), though the difference was not statistically evident. An abundance estimate using conventional distance sampling methods was computed only for the Bransfield Strait. The perpendicular distance data was best fitted by the half-normal model without adjustments. Derived abundance for the surveyed area was 865 humpback whales $(95 \% \mathrm{CI}=656-1,141 ; \mathrm{CV}=14.13)$. This area represents only a small fraction of the Stock $\mathrm{G}$ feeding ground.
\end{abstract}

KEYWORDS: HUMPBACK WHALE; ABUNDANCE; ENCOUNTER RATE; ANTARCTICA; SOUTHERN HEMISPHERE; SURVEY-VESSEL

\section{INTRODUCTION}

The humpback whale, Megaptera novaeangliae, is a cosmopolitan species and occurs in all major ocean basins from tropical to polar waters (e.g. Clapham and Mead, 1999; Dawbin, 1966; Mackintosh, 1965). The species was extensively hunted historically, resulting in global population decline to a very low level (Gambell, 1973). In the Southern Hemisphere, seven breeding stocks are recognised by the International Whaling Commission (IWC, 1998). Both stocks wintering off South America (i.e. Stock G - eastern South Pacific and Stock A - western South Atlantic) were heavily exploited from coastal stations and by the pelagic fleets (e.g. Chittleborough, 1965; Findlay, 2001; Gambell, 1973) and are among the least known breeding stocks. Despite evidence from photo-identification data that whales feeding around the Antarctic Peninsula are part of Stock G (Stevick et al., 2004), controversy remains regarding the feeding ground of whales from Stock A, believed to migrate to somewhere around both the Antarctic Peninsula and South Georgia (e.g. IWC, 1998; Slijper, 1965). Frequent matches between individuals from the Antarctic Peninsula and the eastern South Pacific wintering grounds, as well as the lack of matches between the Peninsula and the western South Atlantic breeding grounds (Acevedo et al., 2007; Dalla Rosa et al., 2004; Rasmussen et al., 2007; Stevick et al., 2004) suggest that the Antarctic Peninsula is a feeding ground for Stock G only and that Stock A feeds elsewhere to the east. Recent findings by Zerbini et al. $(2011 ; 2006)$ show that the migratory destination of Stock A humpback whales is nearby South Georgia and the South Sandwich Islands. These new findings contribute to elucidating the issue concerning the stock structure which is crucial for proper stock assessment. However, other relevant information are necessary for a comprehensive assessment of the current status of humpback whale stocks in the Southern Hemisphere, in particular abundance estimates. Several surveys to estimate whale abundance have been conducted in vast areas of the Southern Ocean, e.g. IWC/IDCR, SOWER or Japanese scouting vessel surveys (Branch and Butterworth, 2001; Reilly et al., 2004) as well as in some breeding grounds (e.g. Bannister and Hedley, 2001; Felix et al., 2005; Findlay et al., 1994; Freitas et al., 2004; Zerbini et al., 2004). Estimates of abundance or any related index (e.g. density or encounter rates) in important concentration areas might be useful for monitoring temporal trends and to compare with corresponding feeding or breeding grounds. Gerlache and Bransfield Straits are important feeding areas for Stock G, where very high encounter rates (Secchi et al., 2002; 2001; Thiele et al., 2004) and site fidelity have been reported (Dalla Rosa et al., 2008; 2001).

Current abundance estimates of humpback whales in the Bransfield Strait are presented and encounter rates between this area and the Gerlache Strait are compared.

\section{MATERIAL AND METHODS}

\section{Study Area and Survey design}

The Bransfield (approximately $62^{\circ} \mathrm{S}$ to $63^{\circ} 45^{\prime} \mathrm{S}$ ) is a wide strait (approximately $50 \mathrm{n}$. mile wide) between western Antarctic Peninsula and the South Shetland Islands. In comparison, the Gerlache Strait (ca. $63^{\circ} 45^{\prime} \mathrm{S}$ to $65^{\circ} 00^{\prime} \mathrm{S}$ ) is a narrow corridor (approximately 5 to 8 n.miles wide or more

\footnotetext{
* Laboratório de Tartarugas e Mamiferos Marinhos/Instituto de Oceanografia, Universidade Federal do Rio Grande (FURG), Cx.P. 474, Rio Grande-RS Brazil, 96201-900.

${ }^{+}$Laboratório de Mamíferos Marinhos, Museu Oceanográfico 'Prof. Eliezer C. Rios', FURG, Cx.P. 379, Rio Grande-RS, Brazil, $96200-970$. 'Laboratório de Estatística Ambiental/Instituto de Matemática e Física, FURG, Cx.P. 474, Rio Grande-RS, Brazil, $96201-900$.

Laboratório de Mamíferos Aquáticos (MAQUA), Departamento de Oceanografia, Universidade do Estado do Rio de Janeiro, Brazil, $20550-013$.

* Marine Mammal Research Unit, University of British Columbia, Vancouver BC, Canada.
} 


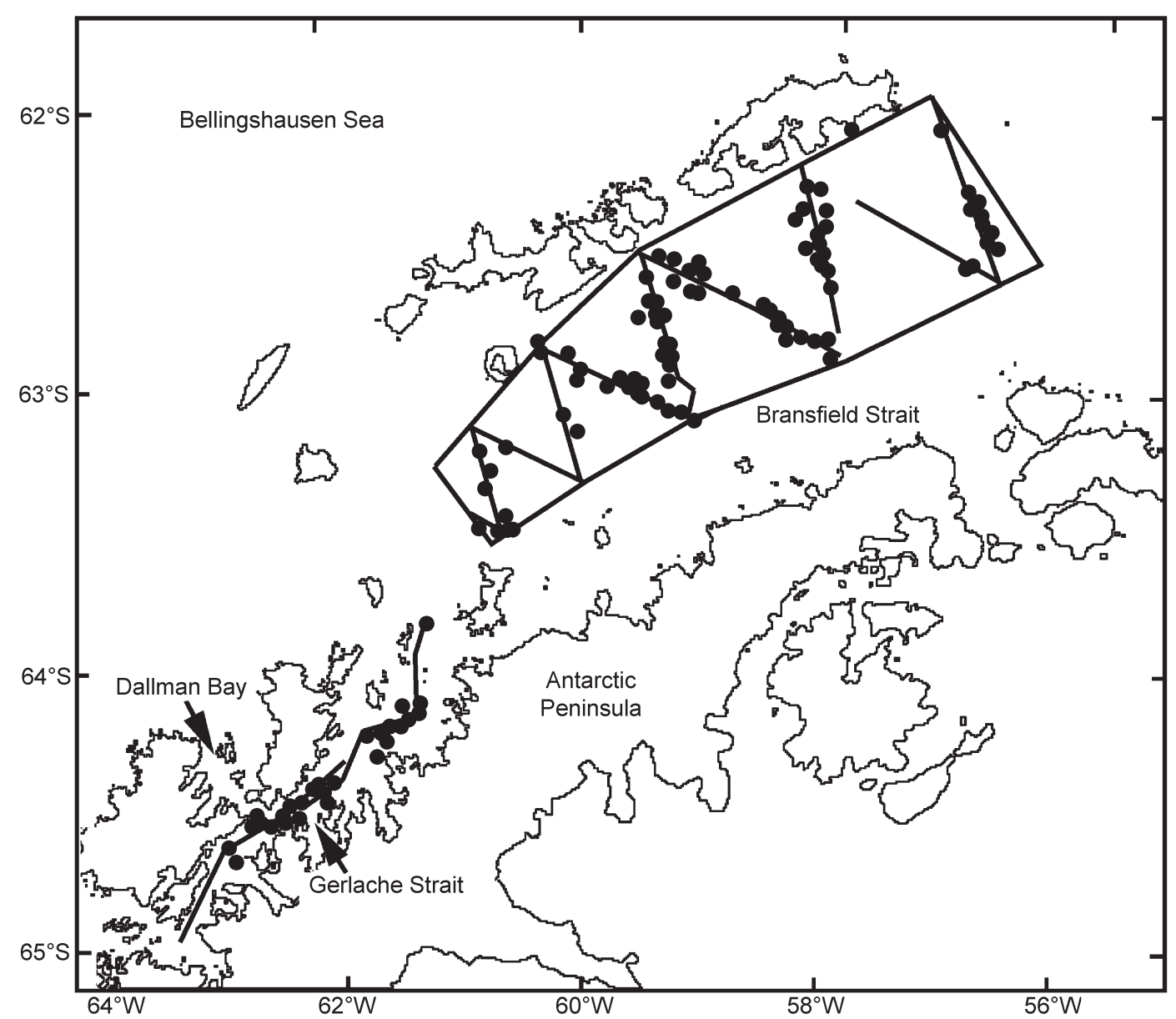

Fig. 1. Survey design and plots of sighting positions in the Gerlache and Bransfield Straits.

in front of large bays) between Brabant and Ansvers Islands and the western Antarctic Peninsula. Its relatively calm waters make cetacean observation easy (Fig. 1).

During the austral summer of 2006, the Projeto Baleias/PROANTAR conducted ship surveys for cetacean sightings in the Gerlache and Bransfield Straits, Antarctic Peninsula region (the boundary between IWC management areas I and II (see Donovan, 1991). In Bransfield, surveys followed nine zig-zag transect lines from the South Shetland Islands towards the Peninsula and back. The start point of the survey in the Bransfield was chosen at random. Areas of poor bathymetry were avoided. This resulted in an unsurveyed strip about 15 n.mile wide westward of the Peninsula. In Gerlache, the tracklines ran along the strait. Tracklines in both Gerlache and Bransfield Straits are shown in Fig. 1. Surveys were conducted in passing mode onboard the Brazilian Navy $75 \mathrm{~m}$ long Oceanographic and Supply Vessel (NApOc) 'Ary Rongel'.

\section{Survey protocol}

Surveys were conducted between 24 January and 9 February. The observation platforms were the exterior wings of the bridge, approximately $12 \mathrm{~m}$ above sea level. One observer at each board of the ship, one data recorder and one person resting rotated their positions every $30 \mathrm{~min}$. The data recorder and occasionally the person on rest helped the observers to identify species and to estimate group size whenever the animals were very far so the observers could keep on scanning the area. Each observer covered one side of the vessel's trackline forward of the beam $\left(90^{\circ}\right.$ quadrant). Searching effort was higher towards the trackline. The searching area of the two observers overlapped approximately $10^{\circ}$ on each side of the trackline. Logistics made independent observation impractical and as a result, observers could hear each other whenever a sight was reported to the data recorder. Whales were searched for with $7 \times 50$ reticled Fujinon binoculars over $80 \%$ of the time and by naked eye. Slight variations in the time observers used the binocular were expected. Ship speed varied around $10 \mathrm{knots}$, depending on the number of growlers and icebergs in the vicinity. Search effort was restricted to sea conditions ranging from Beaufort scale 0 to 5 (inclusive) to reduce its effect on sighting probability. Although visibility and sea state categories tend to be subjective and may vary among observers, their final classification was defined on a common sense basis. Completely clear sky was considered as an excellent visibility condition. When fog was slightly limiting the observer's sight of the horizon, the visibility was classified as moderate. An approximate control of the observer's limit of visibility was obtained whenever possible by using the ship's radar to read distances from growlers and icebergs. Observation effort was halted when visibility was poor (i.e. below 3 n.mile) and sea state was above Beaufort 5 .

For each sighting, the data recorder collected information on species, group size (minimum, best and maximum counting), position, date, time, navigation and environmental conditions. Information regarding sightings, navigation, environmental conditions and effort were stored in the computer using the program Logger (IFAW, 1994). The computer was connected to the ship's navigation system, allowing for real-time GPS position storage. The true heading of the ship, the number of binocular reticles between the animal(s) and the horizon and the radial angle between the 
group and the trackline were recorded immediately after sighting. Detailed checks of the sightings were made during and after the searching effort to identify and exclude probable double counts. Observers were instructed to avoid rounding in both reticle and horizontal angle readings. This information was used to calculate perpendicular distancess of animals to the trackline (e.g. Buckland et al., 2001, p.258; Lerczak and Hobbs, 1998). Lerczak and Hobbs (1998) ${ }^{1}$ provided equations for calculating the radial distance from reticle numbers when horizon is obstructed by land. On such occasions, it was necessary to know the distance between the observer and the land blocking the view to the horizon at the exact angle of that sighting. This approach was used to calculate the perpendicular distance of some of the sightings in Gerlache Strait.

\section{Data analysis}

Only data obtained during searching effort are considered in the analysis (i.e. crew and researcher sightings made 'off effort' were not included).

The encounter rate, defined as the number of whales sighted per nautical mile surveyed, was used as a simple index of humpback whale density, allowing for comparisons between the Gerlache and Bransfield Straits and with previous studies in these areas. The number of sightings in the Bransfield Strait was sufficient for estimating the detection probability.

Abundance $(\hat{N})$ was estimated using distance sampling methods. Its variance and confidence intervals were obtained using the empiric equation of Buckland et al. (2001, p.115).

$$
\hat{N}=\frac{A \cdot n \cdot \hat{E}(s)}{2 \cdot L \cdot E S W \cdot \hat{g}(0)}
$$

where:

$A$ is the survey area;

$n$ is the number of sightings;

$\hat{E}(s)$ is the estimated mean group size of observed groups;

$L$ is the total trackline length;

$E S W$ is the estimated effective strip width; and

$\hat{g}(0)$ is the estimated detection probability on the trackline (assumed to be 1).

Data analysis was performed using the software Distance 5.1 (Thomas et al., 2006). Perpendicular distances were truncated at 3 n.mile and the effective search width was estimated by fitting half-normal and hazard-rate models to the data. Cosine and hermite polynomial series expansions for half-normal function, and cosine and simple polynomial adjustments for hazard-rate were also considered in the set of candidate models. Beaufort sea state was included as a covariate aiming at assessing its potential effects of on the detection probability. The Bayesian Information Criterion (BIC) and Goodness of fit tests were used to select the model that best fit the data.

\section{RESULTS}

\section{Encounter rate}

Total observation effort was 140.11 n.mile in the Gerlache Strait and 313.80 n.mile in the Bransfield Strait. Encounter rate was higher in the Bransfield Strait $(n=100 ; 0.32$ groups

${ }^{1}$ Errata. 1998. Mar. Mammal Sci. 14(4):903
Table 1

Estimated model parameters: $E S W=$ effective strip width (in n.miles); $n / L$ $=$ encounter rates; $\mathrm{DS}=$ density of groups $\left(\right.$ groups n.mile $\left.{ }^{-2}\right) ; E(S)=$ mean group size; $\mathrm{D}=$ density of individuals (whales n.mile ${ }^{-2}$ ); $N=$ abundance in the Bransfield Strait.

\begin{tabular}{lccrc}
\hline Parameter & Point estimate & SE & $\% \mathrm{CV}$ & $95 \% \mathrm{CI}$ \\
\hline$f(0)$ & 0.61 & 0.05 & 8.35 & $0.52-0.72$ \\
$E S W$ & 1.65 & 0.14 & 8.35 & $1.40-1.94$ \\
$n / L$ & 0.32 & - & 10.24 & $0.26-0.39$ \\
$\mathrm{DS}$ & 0.10 & 0.01 & 13.21 & $0.07-0.13$ \\
$E(S)$ & 1.87 & 0.09 & 5.02 & $1.69-2.07$ \\
$\mathrm{D}$ & 0.18 & 0.03 & 14.13 & $0.14-0.24$ \\
$N$ & 865 & - & 14.13 & $656-1,141$ \\
\hline
\end{tabular}

n.mile ${ }^{-1} ; 95 \%$ CI: $\left.0.26-0.39\right)$ than in the Gerlache Strait ( $n$ $=33 ; 0.24$ groups n.mile ${ }^{-1} ; 95 \%$ CI: $0.13-0.44$ ), though the difference was not statistically evident due to the complete overlap of confidence intervals. Mean group size for the Bransfield Strait (1.87; SE = 0.09) was slightly higher than for the Gerlache Strait (1.67; $\mathrm{SE}=0.19)$. Modal group size was two individuals in both areas.

\section{Abundance}

The half-normal model without adjustments resulted in the best fit to perpendicular distance data $\left(\chi^{2}=5.95\right.$; d.f. $=6 ; p$ $=0.428)$. The distribution of perpendicular distances and the fitted detection function are presented in Fig. 2. Abundance was estimated at $865(95 \% \mathrm{CI}=656-1,141 ; \mathrm{CV}=14.13)$ humpback whales in the Bransfield Strait. Model parameters, density and abundance estimates are shown in Table 1.

\section{DISCUSSION}

\section{Encounter rate}

Encounter rates of humpback whales were high in both the Gerlache and Bransfield Straits. Surveys were conducted during humpback whale peak density in the region (see Secchi et al., 2001). Despite some intra and interannual variation, humpback whale density is always relatively high in the Gerlache Strait (Secchi et al., 2002; 2001). These authors found that encounter rates of humpbacks whales in this area were higher than in any other of the surveyed areas in the vicinity of the Antarctic Peninsula. Nevertheless, the encounter rate of humpback whales in the Gerlache Strait in this survey was similar to those obtained during years of suspected lower density of the species in this area (see Dalla Rosa et al., 2005; Marques, 2003; Secchi et al., 2001). Photo-identified individuals have been re-sighted on several

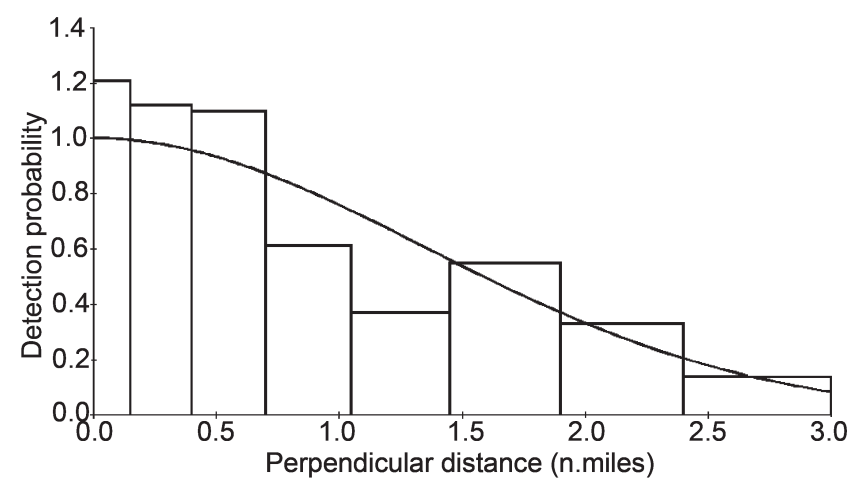

Fig. 2. Half-normal model without adjustment fit to perpendicular distances of humpback whales. 
occasions, both within and between seasons in the Gerlache Strait (Dalla Rosa et al., 2004; 2001). One of two humpback whales satellite tagged in the area in the 2004 austral summer remained in the Gerlache area, including the adjacent Dallman Bay, for more than two months, until the tag batteries probably failed (Dalla Rosa et al., 2008). This provides evidence that the Gerlache Strait is an important feeding ground for humpback whales in the Antarctic Peninsula area. The northern part is generally more productive and the humpback whale density is higher than the southern part of Gerlache Strait (Dalla Rosa et al., 2005). Four whales tagged in the summer of 2006 moved from the Gerlache Strait to the Bransfield Strait within a week (Dalla Rosa et al., 2008), which coincides with the higher encounter rate in the Bransfield Strait. The close proximities of the northern Gerlache and Bransfield Straits might suggest that environmental factors influence both areas similarly. These two areas are influenced by cold deep water masses from the Weddell Sea and warmer waters from the Bellingshausen Sea. Zooplankton sampling around the Antarctic Peninsula found the highest krill biomass in Gerlache and Bransfield Straits (Montu et al., 1994). The seasonal input of nutrients and minerals coincides with blooms of phytoplankton in these areas (Bathmann et al., 1997; Loescher et al., 1997).

\section{Abundance}

No previous abundance estimates were available for the Bransfield Strait as it was the first time a good proportion of the strait could be surveyed within the PROANTAR expeditions. Although the Bransfield Strait is an important concentration area and perhaps, together with the Gerlache Strait, is among the most important humpback whale feeding grounds around the Antarctic Peninsula (see Secchi et al., 2001), the abundance estimate presented here represents probably a very small fraction of breeding Stock G. Because of navigational restrictions, part of the Bransfield Strait was not surveyed. The density was extrapolated only to a surveyed area of approximately 4,780 n.mile ${ }^{2}$. The total Bransfield area is almost twice as large as the surveyed area (approximately 8,085 n.mile ${ }^{2}$ ). The detection probability, assumed to be one, might have caused a slightly underestimation of local abundance as some individuals could have been undetected. Detection probability from shipbased surveys was suggested to be very close to one for humpback whales (e.g. Barlow, 1997). The potential underdetection of animals was minimised by allocating higher observation effort in and near the trackline and by using binoculars most of the time. Only $3 \%$ of the sightings were made by naked-eye. Beaufort sea state was considered as a covariate to assess its effect in the detection probability, however no improvement was obtained (increased BIC and small reduction in the $\mathrm{CV}$ of $f(0)$ ).

Although there is some evidence that humpback whales are not very abundant eastward of the Peninsula (e.g. Secchi et al., 2001), they seem to be fairly abundant further south of the Gerlache Strait towards Marguerite Bay, in the Bellingshausen Sea (Secchi et al., 2001; Thiele et al., 2004). A humpback whale satellite tagged in the Gerlache Strait in the 2004 austral summer moved north to the Bransfield Strait (near Deception Island) and then made a long southward movement in the Bellingshausen Sea until the tag stopped transmitting, when the whale was in the vicinity of Marguerite Bay (Dalla Rosa et al., 2008). Another whale tagged in the 2006 austral summer in the Gerlache Strait also moved to the Marguerite Bay area after spending some time in the Bransfield Strait (Dalla Rosa et al., 2008). Although it is assumed here that humpback whales feeding off the Antarctic Peninsula region represent only individuals from Breeding Stock $\mathrm{G}$, their distribution range in the feeding ground is poorly known, therefore, the size of the unsurveyed fraction remains to be determined. Furthermore, there is recent evidence that a small proportion of Stock $G$ does not migrate to the Antarctic, remaining in the Magellan Strait and Fuegian Channels, considered an alternative feeding ground for part of Stock G (Acevedo et al., 2007). Likewise, abundance estimates for Stock $G$ in its breeding grounds are restricted to relatively small areas (e.g. Castro and González, 2002; Felix et al., 2005; Scheidat, 2001). Consequently, the total abundance of Stock $G$ remains unknown. More comprehensive surveys westward of the Peninsula including the eastern Bellingshausen Sea, Gerlache-Bransfield areas and Marguerite Bay are therefore recommended.

\section{ACKNOWLEDGEMENTS}

The Brazilian Antarctic Programme (PROANTAR) is sponsored by the Interministerial Commission for the Resources of the Sea (CIRM)/Brazilian Navy in collaboration with the Brazilian Council for Scientific Research and Development (CNPq). The authors are indebted to CIRM/Brazilian Navy for the logistical support given to the Project and to $\mathrm{CNPq}$, which has financially supported the Project and the researchers. We would also like to thank the crew of the NApOc 'Ary Rongel', specially the ship commander José Carlos dos Santos Parente (Brazilian Navy) and the onboard SECIRM coordinators for their support to our project. Ygor G. Maia helped us collecting sighting data. E.R. Secchi and L. Dalla Rosa were supported CNPq (PQ 305219/2008-1) and CAPES (grant BEX1339/02-8). This contribution of the Research Group 'Ecologia e Conservação da Megafauna MarinhaEcoMega/CNPq'.

\section{REFERENCES}

Acevedo, J., Rasmussen, K., Félix, F., Castro, C., Llano, M., Secchi, E., Saborío, M.T., Aguayo-Lobo, A., Haase, B., Scheidat, M., Dalla Rosa, L., Olavarria, C., Forestell, P., Acuña, P., Kaufman, G. and Pastene, L.A. 2007. Migratory destinations of humpback whales, Megaptera novaeangliae from the Magellan Strait feeding ground, southeast Pacific. Mar. Mammal Sci. 23(2): 453-63.

Bannister, J.L. and Hedley, S.L. 2001. Southern Hemisphere group IV humpback whales: their status from recent aerial survey. Mem. Queensl. Mus. 47(2): 587-98.

Barlow, J. 1997. Preliminary estimates of cetacean abundance off California, Oregon and Washington based on a 1996 ship survey, and comparisons of passing and closing modes. SWFSC Admin. Rep. No. LJ97-11. 25pp. [Available from SWFSC, PO Box 271, La Jolla, CA].

Bathmann, U.V., Scharek, R., Klaas, C., Dubischar, C.D. and Smetacek, V. 1997. Spring development of phytoplankton biomass and composition in major water masses of the Atlantic sector of the Southern Ocean. Deep-Sea Res. I 44(1-2): 51-67.

Branch, T.A. and Butterworth, D.S. 2001. Estimates of abundance south of $60^{\circ} \mathrm{S}$ for cetacean species sighted frequently on the $1978 / 79$ to $1997 / 98$ IWC/IDCR-SOWER sighting surveys. J. Cetacean Res. Manage. 3(3): 251-70.

Buckland, S.T., Anderson, D.R., Burnham, K.P., Laake, J.L., Borchers, D.L. and Thomas, L. 2001. Introduction to Distance Sampling: Estimating Abundance of Biological Populations. Oxford University Press, Oxford, UK. vi $+x v+432 p p$.

Castro, C. and González, J. 2002. Población de la ballena jorobada Megaptera novaeangliae Balaenopteridae, en el Parque Nacional Machalilla, Ecuador. Doctorate, Universidad Central del Ecuador. 130pp. [In Spanish].

Chittleborough, R.G. 1965. Dynamics of two populations of the humpback whale, Megaptera novaeangliae (Borowski). Aust. J. Mar. Freshwater Res. 16(1): 33-128. 
Clapham, P.J. and Mead, J.G. 1999. Megaptera novaeangliae. Mamm. Species 604: 1-9.

Dalla Rosa, L., Secchi, E.R., Kinas, P.G., Santos, M.C.d.O., Martins, M.B., Zerbini, A.N. and Bethlem, C.P. 2001. Photo-identification of humpback whales, Megaptera novaeangliae, off the Antarctic Peninsula: 1997/98 to 1999/2000. Mem. Queensl. Mus. 47(2): 555-61.

Dalla Rosa, L., Freitas, A., Secchi, E.R., Santos, M.C.O. and Engel, M.H. 2004. An updated comparison of the humpback whale photo-id catalogues from the Antarctic Peninsula and the Abrolhos Bank, Brazil. Paper SC/56/SH16 presented to the IWC Scientific Committee, July 2004, Sorrento, Italy (unpublished). 4pp. [Paper available from the Office of this Journal].

Dalla Rosa, L., Secchi, E.R., Marques, F., Bassoi, M., Santos, M.C.O., Nicolette, R. and Kinas, P.G. 2005. Interannual and small-scale spatial variation in humpback whale encounter rates in the Gerlache Strait, Antarctic: summers 1997-98 to 2004/2005. Paper SC/57/SH8 presented to the IWC Scientific Committee, June 2005, Ulsan, Korea (unpublished). 10pp. [Paper available from the Office of this Journal].

Dalla Rosa, L., Secchi, E., Maia, Y.G., Zerbini, A. and Heide-Jørgensen, M.P. 2008. Movements of satellite-monitored humpback whales on their feeding ground along the Antarctic Peninsula. Polar Biol. 31: 771-81.

Dawbin, W.H. 1966. The seasonal migratory cycle of humpback whales. pp.145-70. In: Norris, K.S. (eds). Whales, Dolphins, and Porpoises. University of California Press, Berkeley and Los Angeles. xv+789pp.

Donovan, G.P. 1991. A review of IWC stock boundaries. Rep. int. Whal. Commn (special issue) 13: 39-68.

Félix, F., Castro, C., Haase, B. and Scheidat, M. 2005. New estimate of the southeastern Pacific humpback whale stock. Abstracts of the 16th Biennial Conference on the Biology of Marine Mammals, December 1216 2005, San Diego, California

Findlay, K.P. 2001. A review of humpback whale catches by modern whaling operations in the Southern Hemisphere. Mem. Queensl. Mus. 47(2): 411-20.

Findlay, K.P., Best, P.B., Peddemors, V.M. and Gove, D. 1994. The distribution and abundance of humpback whales on their southern and central Mozambique winter grounds. Rep. int. Whal. Commn 44: 31120 .

Freitas, A.C., Kinas, P.G., Martins, C.A.C. and Engel, M.H. 2004. Abundance of humpback whales on the Abrolhos Bank wintering ground, Brazil. J. Cetacean Res. Manage. 6(3): 225-30.

Gambell, R. 1973. How whales survive. pp.193-202. In: Calder, N. (eds). Nature in the Round. Weidenfeld and Nicolson, London.

IFAW. 1994. Logger software. International Fund for Animal Welfare, PO Box 193, 411 Main Street, Yarmouth Port, MA 02675, USA.

International Whaling Commission. 1998. Report of the Scientific Committee. Rep. int. Whal. Commn 48:53-118.

Lerczak, J.A. and Hobbs, R.C. 1998. Calculating sighting distances from angular readings during shipboard, aerial, and shore-based marine mammal surveys. Mar. Mammal Sci. 14(3): 590-99. [See Errata. 1998. Mar. Mammal Sci. 14(4):903].

Loescher, B.M., De Bar, H.J.W., De Jong, J.T.M., Veth, C. and Dehairs, F. 1997. The distribution of Fe in the Antarctic Circumpolar Current. DeepSea Res. I 44(1-2): 143-87.

Mackintosh, N.A. 1965. The Stocks of Whales. Fishing News (Books) Ltd, London. 232pp.

Marques, F.F.C. 2003. Modelagem espaco-temporal da distribuicâo e abundância de cetáceos nos Oceanos Atlântico Sul-Ocidental e Antártico. Final report - post-doctoral scholarship, Projeto Baleias/Brazilian Antarctic Program. [In Portuguese].
Montú, M., Gloeden, I.M., Resgalla, C., Jr. and Loureiro Fernandes, L.F. 1994. Krill populations in the Bransfield Strait and neighbouring areas during the summers of 1983, 1984, 1985 and 1987. Nauplius 2: 107-21.

Rasmussen, K., Palacios, D., Calambokidis, J., Saborio, M.T., Dalla Rosa, L., Secchi, E.R., Steiger, G.H., Allen, J.M. and Stone, G. 2007. Southern Hemisphere humpback whales wintering off Central America: insights from water temperature into the longest mammalian migration. Biology Letters 3(3): 302-05.

Reilly, S., Hedley, S., Borberg, J., Hewitt, R., Thiele, D., Watkins, J. and Naganobu, M. 2004. Biomass and energy transfer to baleen whales in the South Atlantic sector of the Antarctic. Deep-Sea Res. II 51: 1397-409.

Scheidat, M. 2001. Abundance, habitat use, behaviour and management of humpback whales (Megaptera novaeangliae) in the Machalilla National Park, Ecuador. Dissertation zur Erlangung des Doktorgrades der Mathematisch-Naturwissenschaftlichen Fakultat der Christian-AlbrechtsUniversitat zu Kiel. [In German].

Secchi, E.R., Dalla Rosa, L., Kinas, P.G., Santos, M.C.O., Zerbini, A.N., Bassoi, M. and Moreno, I.B. 2001. Encounter rates of whales around the Antarctic peninsula with special reference to humpback whales, Megaptera novaeangliae, in the Gerlache strait: 1997/98 to 1999/2000. Mem. Queensl. Mus. 47(2): 571-78.

Secchi, E.R., Dalla Rosa, L., Bassoi, M., Santos, M.C.O., Danilewicz, D., Flores, P.A., Moreno, I.B. and Kinas, P.G. 2002. Intra and interannual trends in density of humpback whales, Megaptera novaeangliae, in the Gerlache strait: summers 1997/98 to 2001/2002. Paper SC/54/H12 presented to the IWC Scientific Committee, April 2002, Shimonoseki, Japan (unpublished). [Paper available from the Office of this Journal].

Slijper, E.J. 1965. A Hundred Years of Modern Whaling. Netherlands Commmission for International Nature Protection, Amsterdam. 43pp.

Stevick, P.T., Aguayo, A., Allen, J., Avila, I.C., Capella, J., Castro, C., Chater, K., Dalla Rosa, L., Engel, M.H., Felix, F., Florez-Gonzalez, L., Freitas, A., Haase, B., Llano, M., Lodi, L., Munoz, E., Olavarria, C., Secchi, E., Scheidat, M. and Siciliano, S. 2004. Migrations of individually identified humpback whales between the Antarctic peninsula and South America. J. Cetacean Res. Manage. 6(2): 109-13.

Thiele, D., Chester, E.T., Moore, S.E., Sirovic, A., Hildebrand, J.A. and Friedlander, A.S. 2004. Seasonal variability in whale encounters in the western Antarctic Peninsula. Deep-Sea Res. II 51(17-19): 2311-25.

Thomas, L., Laake, J.L., Strindberg, S., Marques, F.F.C., Buckland, S.T., Borchers, D.L., Anderson, D.R., Burnham, K.P., Hedley, S.L., Pollard, J.H., Bishop, J.R.B. and Marques, T.A. 2006. Distance 5.0. Release 2. Research Unit for Wildlife Population Assessment, University of St Andrews, UK. [Available from: http ://www.ruwpa.st-and.ac.uk/ distance/].

Zerbini, A.N., Andriolo, A., Da Rocha, J.M., Simoes-Lopes, P.C., Siciliano, S., Pizzorno, J.L., Waite, J.M., DeMaster, D.P. and VanBlaricom, G.R. 2004. Winter distribution and abundance of humpback whales (Megaptera novaengliae) off northeastern Brazil. J. Cetacean Res. Manage. 6(1): 101-07.

Zerbini, A.N., Andriolo, A., Heide-Jørgensen, M.P., Pizzorno, J.L., Maia, Y.G., VanBlaricom, G.R., DeMaster, D.P., Simões-Lopes, P.C., Moreira, S. and Bethlem, C. 2006. Satellite-monitored movements of humpback whales (Megaptera novaeangliae) in the Southwest Atlantic Ocean. Mar. Ecol. Prog. Ser 313: 295-304.

Zerbini, A.N., Andriolo, A., Heide-Jørgensen, M.P., Moreira, S.C., Pizzorno, J.L., Maia, Y.G., VanBlaricom, G.R. and DeMaster, D.P. 2011. Migration and summer destinations of humpback whales (Megaptera novaeangliae) in the western South Atlantic Ocean. J. Cetacean Res. Manage. (special issue 3): 113-118. 